\title{
Seismic activity on the territory of Slovakia in 2019
}

\author{
Róbert KYSEL ${ }^{1,2, *} \mathbb{D}$, Andrej $\mathrm{CIPCIAR}^{1,2}$ (D) Kristián $\mathrm{CSICSAY}^{1}$ (D), \\ Lucia FOJTÍKOVÁ ${ }^{1,4}$ (D), Martin ŠUGÁR ${ }^{1,3}$ (D), Jozef KRISTEK ${ }^{1,2}$ (D) \\ ${ }^{1}$ Earth Science Institute of the Slovak Academy of Sciences, \\ Dúbravská cesta 9, P. O. Box 106, 84005 Bratislava, Slovak Republic \\ ${ }^{2}$ Faculty of Mathematics, Physics and Informatics, Comenius University in Bratislava, \\ Mlynská dolina, 84248 Bratislava, Slovak Republic \\ ${ }^{3}$ Faculty of Natural Sciences, Comenius University in Bratislava, \\ Mlynská dolina, Ilkovičova 6, 84215 Bratislava, Slovak Republic \\ ${ }^{4}$ Institute of Rock Structure and Mechanics of the Czech Academy of Sciences, \\ V Holešovičkách 94/41, 182 09, Prague 8, Czech Republic
}

\begin{abstract}
The National Network of Seismic Stations of Slovakia (NNSS) consists of eight short period and five broadband permanent seismic stations and a data centre located at the Earth Science Institute of the Slovak Academy of Sciences (ESI SAS). The NNSS recorded and detected 11,487 seismic events from all epicentral distances in 2019. Totally 91 earthquakes originated in the territory of Slovakia in 2019. This paper provides basic information on the configuration of the NNSS, routine data processing, seismic activity on the territory of Slovakia in 2019 as well as macroseismic observations collected in 2019.
\end{abstract}

Key words: Slovakia, National Network of Seismic Stations, seismicity, macroseismic observations

\section{Introduction}

The seismic activity on the territory of Slovakia and adjacent areas has been reported on the daily basis by the so called Seismo Reports published on the web sites of the Department of Seismology, ESI SAS http://www.seismo logy.sk/Seismo_Reports/reports.html and in annual reports as a part of the project Partial monitoring system - Geological factors (Liščák et al., 2020, in preparation) which is solved with a contract between ESI SAS and State Geological Institute of Dionýz Štúr. The aim of this paper is to provide a quick overview of earthquakes which originated on the territory of Slovakia or were macroseismically felt on the territory of Slovakia in 2019.

\footnotetext{
*corresponding author: e-mail: robert.kysel@savba.sk
} 


\section{Seismic stations operating in 2019}

The seismic monitoring of the Slovak territory is provided by the NNSS operated by the ESI SAS (ESI SAS, 2004; Csicsay et al., 2018), Local Seismic Network in Eastern Slovakia operated by the Faculty of Mathematics, Physics and Informatics of the Comenius University in Bratislava and local network of seismic stations around NPPs Jaslovské Bohunice and Mochovce operated by Progseis Ltd. company. The networks of seismic stations cooperate, and the exchange of data is on the regular basis. The positions of the seismic stations on the territory of Slovakia are shown in Fig. 1.

In 2019 the NNSS consisted of thirteen permanent seismic stations, from which eight are short period and five are broadband. Broadband stations are: Červenica (CRVS; temporarily out of operation), Kolonické sedlo (KOLS), Modra (MODS), Vyhne (VYHS) and Bratislava - Železná studnička (ZST). Short period stations are: Hurbanovo (HRB), Izabela (IZAB), Iža (SRO1), Kečovo (KECS), Liptovská Anna (LANS), Moča (SRO2), Stebnícka Huta (STHS) and Šrobárová (SRO). The HRB is the oldest NNSS seismic station that has been in operation since 1909 (Pajdušák, 1997). In 2019 the ZST station was upgraded by a broadband sensor Metrozet-MBB2 and the digitizer was changed to a modern 32-bit version too. In the VYHS station

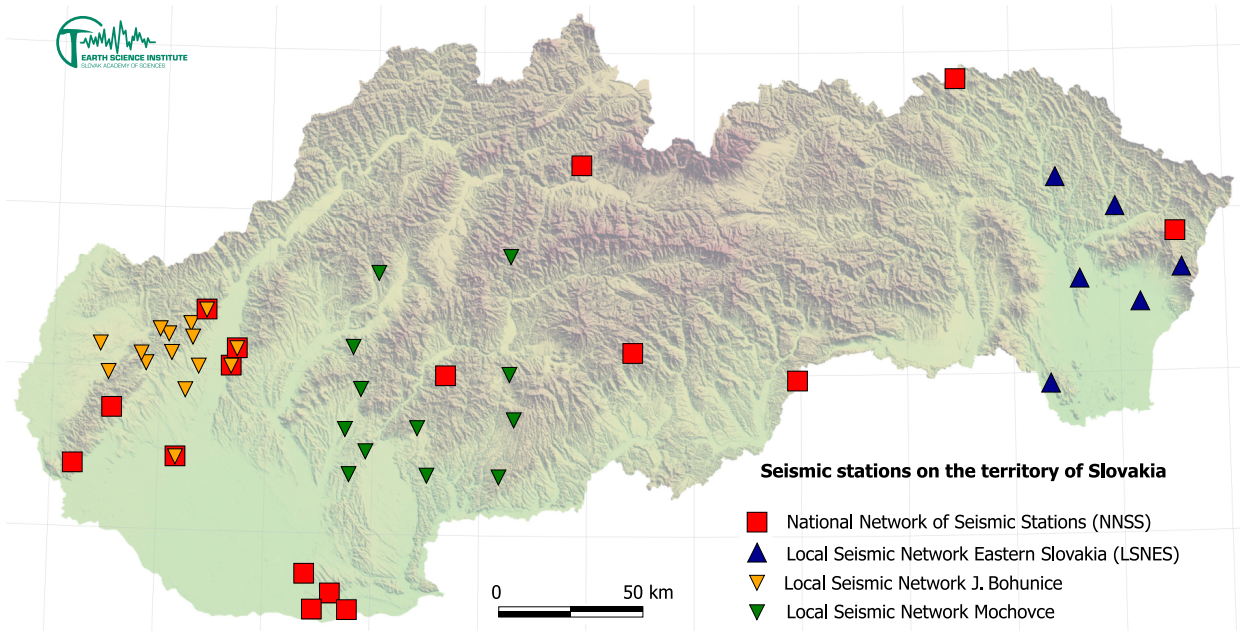

Fig. 1. Seismic stations operational on the territory of Slovakia in 2019. 
we started the upgrade for a new broadband sensor Guralp-3T. The NNSS permanent seismic stations and their instrumentation are summarized in Table 1. More details can be found on the web page http://www.seismo logy.sk/National_Network.

Table 1. Equipment of seismic stations of the NNSS operating in 2019.

\begin{tabular}{|c|c|c|c|c|c|c|c|c|}
\hline Station & $\begin{array}{c}\text { ISC } \\
\text { code }\end{array}$ & $\begin{array}{c}\text { Lat. } \\
{\left[{ }^{\circ} \mathbf{N}\right]}\end{array}$ & $\begin{array}{c}\text { Long. } \\
{\left[{ }^{\circ} \mathbf{E}\right]}\end{array}$ & $\begin{array}{c}\text { Alt. } \\
{[\mathbf{m}]}\end{array}$ & Sensor & DAS & $\begin{array}{c}\text { Sampl. } \\
\text { freq. }\end{array}$ & $\begin{array}{c}\text { Data } \\
\text { format }\end{array}$ \\
\hline $\begin{array}{c}\text { Bratislava } \\
\text { Źel. Studnička }\end{array}$ & ZST & 48.196 & 17.102 & 250 & $\begin{array}{c}\text { Metrozet } \\
- \text { MBB2 }\end{array}$ & Wave32 & $100 /$ sec & mSEED \\
\hline Vyhne & VYHS & 48.493 & 18.836 & 450 & STS-2 & Wave24 & $100 /$ sec & mSEED \\
\hline Modra-Piesok & MODS & 48.373 & 17.277 & 520 & STS-2 & Wave32 & $100 /$ sec & mSEED \\
\hline Hurbanovo & HRB & 47.873 & 18.192 & 115 & $\begin{array}{c}2 \times \\
\text { Mainka }\end{array}$ & Analog & - & $\begin{array}{c}\text { smoked } \\
\text { paper }\end{array}$ \\
\hline Izabela & IZAB & 48.569 & 19.713 & 450 & $3 \times$ SM3 & Wave24 & $100 /$ sec & mSEED \\
\hline Iža & SRO1 & 47.7622 & 18.2328 & 111 & LE3D & PCM & $20 /$ sec & mSEED \\
\hline Kečovo & KECS & 48.483 & 20.486 & 345 & LE3D & Wave24 & $100 /$ sec & mSEED \\
\hline Kolonické sedlo & KOLS & 48.933 & 22.273 & 460 & $\begin{array}{c}\text { Guralp- } \\
6 \text { T-30s }\end{array}$ & Wave32 & $100 / \mathrm{sec}$ & mSEED \\
\hline Liptovská Anna & LANS & 49.151 & 19.468 & 710 & LE3D & SEMS & $100 /$ sec & mSEED \\
\hline Moča & SRO2 & 47.763 & 18.394 & 109 & $\begin{array}{c}\text { Guralp- } \\
40 T-1 s\end{array}$ & Wave24 & $100 /$ sec & mSEED \\
\hline Stebnícka Huta & STHS & 49.417 & 21.244 & 534 & LE3D & Wave24 & $100 / \mathrm{sec}$ & mSEED \\
\hline Šrobárová & SRO & 47.813 & 18.313 & 150 & $\begin{array}{c}3 \times \\
\text { SKM-3 }\end{array}$ & Wave24 & $100 / \mathrm{sec}$ & mSEED \\
\hline
\end{tabular}

Four additional short period seismic stations have been operated on the jointly bases of ESI SAS and other institutions. The seismic stations Banka (BAN), Podolie (POD) and Jalšové (JAL) located in the Little Carpathians have been operated in cooperation with Progseis Ltd. company and the Institute of Rock Structure and Mechanics of the Czech Academy of Sciences (IRSM CAS) (Fojtíková et al., 2015). The seismic station Pusté Úlany (PULA) has been operated in cooperation with the IRSM CAS. These stations have been installed as temporary seismic stations.

In 2019 we signed the Memoranda of Collaboration for the Project PACASE: Pannonian-Carpathian-Alpine Seismic Experiment which is a dense array of seismic stations in the region of the Carpathians, Pannonian Basin and Eastern Alps and a part of the Bohemian Massif and makes a connection between the AlpArray Seismic Network and planned AdriaArray net- 
work. We hope that the dense network of seismic stations in the PannonianCarpathian region (Hetényi et al., 2019) will help to calculate focal mechanism of localized earthquakes in this region and to understand the seismic regime and tectonic evolution of geological units in the CarpathianPannonian basin.

In the end of 2019 a very ambitious project "CAPABLE - CArpathian PAnnonian Basin Lithosphere Enquiry" was approved for funding within Visegrad Fund where ESI SAS is a project partner. For more information about this project see https://www.ig.cas.cz/en/about/visegrad-cap apable/.

\section{Data processing}

Digital data from all NNSS stations (except the analog seismic station HRB) are transferred in real-time to the data centre at the ESI SAS either by the internet or satellite telemetry. Software package SeisComp3 (Weber at al., 2007) and SeedLink server are used for data acquisition and exchange.

Beside observations from the NNSS stations the data centre at ESI SAS also use the data from the above-mentioned local networks of seismic stations in Slovakia and observations from networks of neighbouring countries: Austrian Seismic Network (ZAMG - Zentralanstalt für Meterologie und Geodynamik, 1987), Czech Regional Seismic Network (Institute of Geophysics, Academy of Sciences of the Czech Republic, 1973), Hungarian National Seismological Network (Kövesligethy Radó Seismological Observatory, 1992), Local seismological network for monitoring NPP Dukovany (Institute of Physics of the Earth Masaryk University, 2014), GEOFON Seismic Network (GEOFON Data Centre, 1993), Polish Seismological Network. These stations form a so-called Regional Virtual Network of ESI SAS that consists of approximately 55 seismic stations.

Routine analysis of the digital recordings at the ESI SAS has been performed by the Unix package Seismic handler (Stammler, 1993). Interactive locations of seismic events within Seismic Handler are performed by external program LocSat. The collected digital observations are manually processed on the daily basis. The epicentre locations are based on the IASP91 travel-time curves. Local magnitudes have been determined from the maximum vertical trace amplitudes of $\mathrm{Sg}$ waves, using the pre-defined Seismic 
Handler formula for local events. Continuous raw seismic data from the NNSS are stored in a local archive and seismic data interpretations (together with information on equipment of stations) are stored in a web accessible database.

\section{Seismic activity in 2019}

The NNSS analyzed 11,487 local, regional and teleseismic events in 2019. More than 39,000 seismic phases were determined. Seismic events identified as quarry blasts were excluded from further processing and were not included in the event statistics. All events recorded by the NNSS and analyses at the data centre at ESI SAS has been reported in the so called Seismo Reports and published on the above-mentioned web sites of the Department of Seismology, ESI SAS.

Altogether 91 seismic events located by the NNSS originated in the territory of Slovakia in 2019 (Fig. 2). Known quarry blasts are not included in this number. 24 earthquakes reached local magnitude 1.0 or more and are listed in Table 2. The strongest earthquake occurred on July 13 at 12:07 UTC in Levoča Mts. with local magnitude $M_{L} 3.0$.

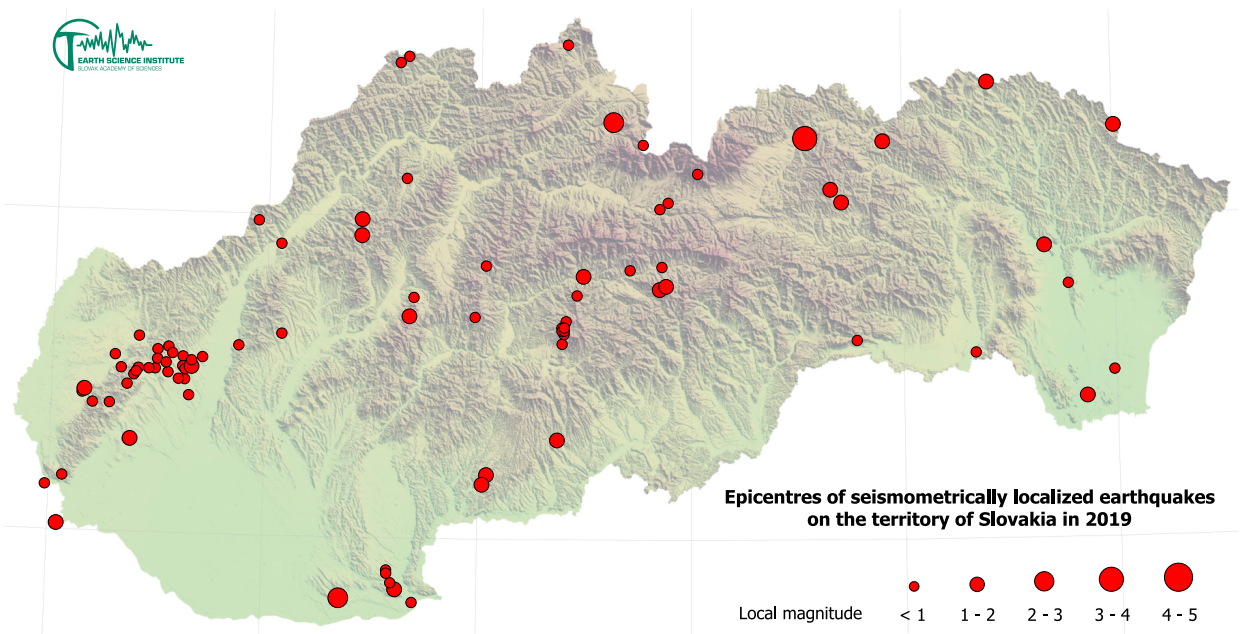

Fig. 2. Map of epicentres of local earthquakes originated on the territory of Slovakia in 2019. Diameters of the circles are proportional to local magnitudes. 
Table 2. List of earthquakes originated on the territory of Slovakia in 2019 with $M_{L} \geq 1.0$.

\begin{tabular}{|c|c|c|c|c|c|c|c|}
\hline$\frac{\text { Date }}{[\text { YYYY-MM-DD] }}$ & $\begin{array}{c}\text { Origin Time } \\
\text { (UTC) } \\
\text { [HH:MM:SS] }\end{array}$ & $\begin{array}{l}\text { Lat. } \\
{\left[{ }^{\circ} \mathbf{N}\right]}\end{array}$ & $\begin{array}{l}\text { Lon. } \\
{\left[{ }^{\circ} \mathbf{E}\right]}\end{array}$ & $\begin{array}{c}\text { Depth } \\
{[\mathrm{km}]}\end{array}$ & $\begin{array}{c}M_{L} \\
{[\mathrm{NNSS}]}\end{array}$ & $\begin{array}{c}\boldsymbol{I}_{0} \\
{\left[{ }^{\circ} \mathbf{E M S}\right]}\end{array}$ & Region \\
\hline 2019-01-29 & $07: 47: 32.97$ & 47.84 & 18.62 & 0 & 1.6 & & $\begin{array}{l}\text { Šamorín - } \\
\text { Komárno - } \\
\text { Štúrovo }\end{array}$ \\
\hline 2019-01-30 & $10: 22: 54.73$ & 49.05 & 20.71 & 0 & 1.5 & & Levoča Mts. \\
\hline 2019-02-15 & 04:43:00.66 & 48.44 & 17.15 & 0 & 1.0 & & $\begin{array}{c}\text { Little } \\
\text { Carpathians }\end{array}$ \\
\hline 2019-03-28 & $12: 48: 06.17$ & 49.42 & 21.41 & 9 & 1.5 & & Low Beskids \\
\hline 2019-04-08 & 04:54:30.05 & 48.94 & 18.44 & 3 & 1.6 & & Strážov Mts. \\
\hline 2019-04-13 & 04:04:04:13 & 48.78 & 19.85 & 0 & 1.6 & & Muráň Plain \\
\hline 2019-04-15 & $03: 42: 30.14$ & 48.99 & 18.44 & 0 & 1.5 & 3 & Strážov Mts. \\
\hline 2019-04-22 & 07:56:17.00 & 48.31 & 19.37 & 0 & 1.4 & & Krupina Plain \\
\hline 2019-04-23 & $14: 12: 26.47$ & 49.24 & 20.91 & 6 & 1.8 & & Čergov \\
\hline 2019-05-03 & 20:20:11.15 & 48.82 & 19.49 & 0 & 1.4 & 3 & $\begin{array}{l}\text { Upper Hron } \\
\text { River region }\end{array}$ \\
\hline 2019-06-14 & $11: 42: 09.24$ & 48.29 & 17.37 & 2 & 1.0 & & $\begin{array}{c}\text { Little } \\
\text { Carpathians }\end{array}$ \\
\hline 2019-07-10 & $20: 51: 18.74$ & 48.69 & 18.67 & 0 & 1.2 & & Vtáčnik Mts. \\
\hline 2019-07-13 & $12: 07: 48.39$ & 49.25 & 20.54 & 4 & 3.0 & $3-4$ & Levoča Mts. \\
\hline 2019-07-28 & 22:59:06.67 & 48.02 & 17.04 & 2 & 1.4 & & $\begin{array}{l}\text { Šamorín - } \\
\text { Komárno - } \\
\text { Śtúrovo }\end{array}$ \\
\hline 2019-08-02 & $17: 50: 28.15$ & 47.81 & 18.36 & 0 & 2.0 & & $\begin{array}{l}\text { Šamorín - } \\
\text { Komárno - } \\
\text { Śtúrovo }\end{array}$ \\
\hline 2019-08-15 & $11: 46: 28.54$ & 49.09 & 20.66 & 0 & 1.0 & & Levoča Mts. \\
\hline 2019-08-21 & 04:52:41.19 & 48.52 & 17.65 & 0 & 1.3 & & $\begin{array}{c}\text { Little } \\
\text { Carpathians }\end{array}$ \\
\hline 2019-09-15 & 00:44:07.12 & 49.30 & 19.63 & 0 & 2.1 & 4 & Orava region \\
\hline 2019-09-25 & $00: 32: 15.73$ & 48.79 & 19.88 & 0 & 1.0 & & Muráň Plain \\
\hline 2019-09-28 & $14: 46: 49.81$ & 48.44 & 21.86 & 0 & 1.1 & & $\begin{array}{l}\text { East Slovak } \\
\text { Lowland }\end{array}$ \\
\hline 2019-10-02 & $13: 16: 35.44$ & 49.28 & 22.01 & 10 & 1.5 & & Low Beskids \\
\hline $2019-10-23$ & $04: 34: 43.85$ & 48.20 & 19.04 & 0 & 1.2 & & Krupina Plain \\
\hline
\end{tabular}


Table 2. Continued from the previous page.

\begin{tabular}{|c|c|c|c|c|c|c|c|}
\hline $\begin{array}{c}\text { Date } \\
\text { [YYYY-MM-DD] }]\end{array}$ & $\begin{array}{c}\text { Origin Time } \\
\text { (UTC) } \\
{[\text { HH:MM:SS }]}\end{array}$ & $\begin{array}{c}\text { Lat. } \\
{\left[{ }^{\circ} \mathbf{N}\right]}\end{array}$ & $\begin{array}{c}\text { Lon. } \\
{\left[{ }^{\circ} \mathbf{E}\right]}\end{array}$ & $\begin{array}{c}\text { Depth } \\
{[\mathbf{k m}]}\end{array}$ & $\begin{array}{c}\boldsymbol{M}_{\boldsymbol{L}} \\
{[\mathbf{N N S S}]}\end{array}$ & $\begin{array}{c}\boldsymbol{I}_{0} \\
{\left[{ }^{\circ} \mathbf{E M S}\right]}\end{array}$ & Region \\
\hline $2019-11-11$ & $14: 31: 46.17$ & 48.91 & 21.67 & 11 & 1.1 & & $\begin{array}{c}\text { Eastern Slovak } \\
\text { Upland }\end{array}$ \\
\hline $2019-12-10$ & $15: 22: 00.43$ & 48.17 & 19.02 & 0 & 1.4 & & Krupina Plain \\
\hline
\end{tabular}

The seismicity of the Slovak territory is dominated by the Little Carpathians and Komárno seismic source zones (Hók et al., 2016). The strongest earthquake in the Little Carpathians source zone was detected on the July 21 at 04:52 UTC with local magnitude $M_{L}$ 1.3. The strongest earthquake in the Komárno source zone was detected on the August 2 at 17:50 UTC with local magnitude $M_{L}$ 2.0. Although the low level of seismic activity from the last decades remained unchanged also in 2019, these two source zones remain of the primary interest for the monitoring of seismic activity within the territory of Slovakia.

\section{Macroseismic observations}

Four earthquakes were macroseismically felt on the territory of Slovakia in 2019 (Table 3), all of them with the epicentre on the territory of Slovakia (Fig. 3). All of these four earthquakes were also seismometrically observed and processed. Intensities were estimated by the European Macroseismic Scale 1998 (EMS-98) introduced by Grünthal (1998).

The earthquake on April 15 at 3:42 UTC with epicentre in Strážov Mts.

Table 3. List of macroseismically observed earthquakes on the territory of Slovakia in 2019.

\begin{tabular}{|c|c|c|c|c|c|c|c|}
\hline $\begin{array}{c}\text { Date } \\
{[\mathbf{Y Y Y Y}-\mathbf{M M - D D}]}\end{array}$ & $\begin{array}{c}\text { Origin Time } \\
\text { (UTC) } \\
{[\mathbf{H H : M M : S S}]}\end{array}$ & $\begin{array}{c}\text { Lat. } \\
{\left[{ }^{\circ} \mathbf{N}\right]}\end{array}$ & $\begin{array}{c}\text { Lon. } \\
{\left[{ }^{\circ} \mathbf{E}\right]}\end{array}$ & $\begin{array}{c}\text { Depth } \\
{[\mathbf{k m}]}\end{array}$ & $\begin{array}{c}\boldsymbol{M}_{\boldsymbol{L}} \\
{[\mathbf{N N S S}]}\end{array}$ & $\begin{array}{c}\boldsymbol{I}_{0} \\
{\left[{ }^{\circ} \mathbf{E M S}\right]}\end{array}$ & Region \\
\hline $2019-04-15$ & $03: 42: 30.1$ & 48.99 & 18.44 & 0 & 1.5 & 3 & Strážov Mts. \\
\hline $2019-05-03$ & $20: 20: 11.2$ & 48.82 & 19.49 & 0 & 1.4 & 3 & $\begin{array}{c}\text { Upper Hron } \\
\text { River region }\end{array}$ \\
\hline $2019-07-13$ & $12: 07: 48.4$ & 49.25 & 20.54 & 4 & 3.0 & $3-4$ & Levoča Mts. \\
\hline $2019-09-15$ & $00: 44: 07.1$ & 49.30 & 19.63 & 0 & 2.1 & 4 & Orava region \\
\hline
\end{tabular}




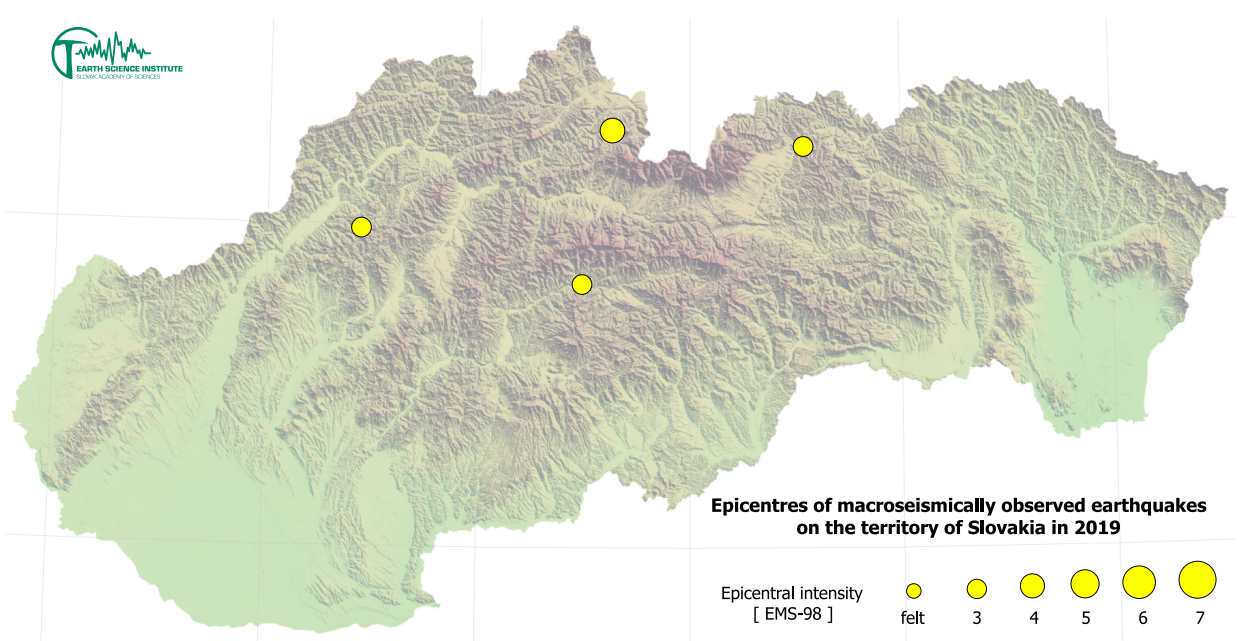

Fig. 3. Map of epicentres of macroseimically observed earthquakes on the territory of Slovakia in 2019. Diameters of the circles are proportional to epicentral intensity.

located between municipalities Mojtín and Pružina and local magnitude 1.5 was macroseismically felt on 1 location (Table 4). 1 macroseimic questionnaire was filled. The epicentral intensity was determined at $3^{\circ}$ EMS-98.

The earthquake on May 3 at 20:20 UTC with epicentre in Upper Hron River region located between municipalities Lopej and Predajná and local magnitude 1.4 was macroseismically felt on 5 locations (Table 5). 21 macroseimic questionnaires were filled. People reported moderate shaking and acoustic effects - detonation. The epicentral intensity was determined at $3^{\circ}$ EMS-98.

The earthquake on July 13 at 12:07 UTC with epicentre in northern part of Levoča Mts. near Podolínec and local magnitude 3.0 was macroseismically felt on 18 locations (Table 6). 91 macroseismic questionnaires were filled. The event was described as a light trembling. Several people reported rattling of glasses and shift of small objects. The epicentral intensity was determined at $3-4^{\circ}$ EMS-98.

The earthquake on September 15 at 00:44 UTC with epicentre in Orava region located between municipalities Habovka and Zuberec and local magnitude 2.1 was macroseismically felt on 2 locations (Table 7). 2 macroseimic questionnaires were filled. The epicentral intensity was determined at $4^{\circ}$ EMS-98. 
Table 4. Macroseismic observations for April 15, 2019 earthquake, 3:42 UTC.

\begin{tabular}{|l|c|c|c|c|}
\hline Locality & $\begin{array}{c}\text { Lat. } \\
{\left[{ }^{\circ} \mathbf{N}\right]}\end{array}$ & $\begin{array}{c}\text { Lon. } \\
{\left[{ }^{\circ} \mathbf{E}\right]}\end{array}$ & $\begin{array}{c}\text { No. of } \\
\text { questionnaires }\end{array}$ & $\begin{array}{c}\boldsymbol{I} \\
{\left[{ }^{\circ} \text { EMS-98 }\right]}\end{array}$ \\
\hline Mojtín & 48.984 & 18.410 & 1 & 3 \\
\hline
\end{tabular}

Table 5. Macroseismic observations for May 3, 2019 earthquake, 20:20 UTC.

\begin{tabular}{|l|c|c|c|c|}
\hline Locality & $\begin{array}{c}\text { Lat. } \\
{\left[{ }^{\circ} \mathbf{N}\right]}\end{array}$ & $\begin{array}{c}\text { Lon. } \\
{\left[{ }^{\circ} \mathbf{E}\right]}\end{array}$ & $\begin{array}{c}\text { No. of } \\
\text { questionnaires }\end{array}$ & $\begin{array}{c}\boldsymbol{I} \\
{\left[{ }^{\circ} \text { EMS-98 }\right]}\end{array}$ \\
\hline Predajná & 48.820 & 19.463 & 14 & 3 \\
\hline Nemecká & 48.812 & 19.435 & 3 & 3 \\
\hline Jasenie & 48.863 & 19.447 & 2 & 3 \\
\hline Lopej & 48.818 & 19.496 & 1 & 3 \\
\hline Podbrezová & 48.815 & 19.522 & 1 & 3 \\
\hline
\end{tabular}

Table 6. Macroseismic observations for July 13, 2019 earthquake, 12:07 UTC.

\begin{tabular}{|l|c|c|c|c|}
\hline Locality & $\begin{array}{c}\text { Lat. } \\
{\left[{ }^{\circ} \mathbf{N}\right]}\end{array}$ & $\begin{array}{c}\text { Lon. } \\
{\left[{ }^{\circ} \mathbf{E}\right]}\end{array}$ & $\begin{array}{c}\text { No. of } \\
\text { questionnaires }\end{array}$ & $\begin{array}{c}\text { I } \\
{\left[{ }^{\circ} \text { EMS-98 }\right]}\end{array}$ \\
\hline Vyšné Ružbachy & 49.305 & 20.564 & 10 & $3-4$ \\
\hline Stará Lubovňa & 49.311 & 20.696 & 26 & 3 \\
\hline Hniezdne & 49.304 & 20.632 & 14 & 3 \\
\hline Podolínec & 49.258 & 20.538 & 12 & 3 \\
\hline Nižné Ružbachy & 49.282 & 20.580 & 6 & 3 \\
\hline Nová Lubovňa & 49.275 & 20.685 & 6 & 3 \\
\hline Kamienka & 49.332 & 20.617 & 2 & 3 \\
\hline Lacková & 49.309 & 20.595 & 1 & 3 \\
\hline Lomnička & 49.252 & 20.570 & 1 & 3 \\
\hline Starina & 49.057 & 22.258 & 1 & 3 \\
\hline Starý Smokovec & 49.131 & 20.207 & 1 & felt \\
\hline Forbasy & 49.299 & 20.618 & 3 & felt \\
\hline Kolačkov & 49.263 & 20.631 & 3 & felt \\
\hline Jakubany & 49.248 & 20.694 & 1 & felt \\
\hline Jarabina & 49.336 & 20.658 & 1 & felt \\
\hline Litmanová & 49.370 & 20.623 & 1 & felt \\
\hline Tatranská Kotlina & 49.228 & 20.320 & 1 & felt \\
\hline Velký Lipník & 49.373 & 20.506 & 1 & \\
\hline
\end{tabular}


Table 7. Macroseismic observations for September 15, 2019 earthquake, 00:44 UTC.

\begin{tabular}{|l|c|c|c|c|}
\hline Locality & $\begin{array}{c}\text { Lat. } \\
{\left[{ }^{\circ} \mathbf{N}\right]}\end{array}$ & $\begin{array}{c}\text { Lon. } \\
{\left[{ }^{\circ} \mathbf{E}\right]}\end{array}$ & $\begin{array}{c}\text { No. of } \\
\text { questionnaires }\end{array}$ & $\begin{array}{c}\boldsymbol{I} \\
{\left[{ }^{\circ} \text { EMS-98 }\right]}\end{array}$ \\
\hline Habovka & 49.276 & 19.607 & 1 & 4 \\
\hline Zuberec & 49.254 & 19.663 & 1 & 3 \\
\hline
\end{tabular}

\section{Conclusion and discussion}

The NNSS is operated by the ESI SAS, Bratislava. Data from all stations (except station HRB) are transferred in real-time to the data centre at Bratislava. Data processing and routine analysis are performed digitally by interactive seismological software Seismic Handler. Digital data are accessible both on-line and off-line in standard data format. So called Seismo Reports of seismic events recorded by NNSS are published on the web page of the ESI SAS http://www.seismology.sk/SeismoReports/reports.html.

In the years 2018 and 2019 we received financial contribution from the Office of Slovak Academy of Sciences for the upgrade of the outdated instrumentation. From this contribution ESI SAS upgraded two of the broadband seismic stations: VYHS and ZST.

Epicentres and local magnitudes were determined for 91 earthquakes originated in the territory of Slovakia in 2019. Weak seismic activity was recorded from several seismic source zones: Little Carpathians, Komárno, Muráň Plain, Krupina Plain and Strážov Mts.

Acknowledgements. The authors have been supported by the Slovak Foundation Grant VEGA 2/0144/19, the Slovak Research and Development Agency Grant APVV-16-0146 and the Visegrad Fund Grant No. 21930053.

\section{References}

Csicsay K., Cipciar A., Fojtíková L., Kristeková M., Gális M., Srbecký M., Chovanová Z., Bystrický E., Kysel R., 2018: The National Network of Seismic Stations of Slovakia - Current state after 13 years in operation from the project of modernization and enhancement. Contrib. Geophys. Geod., 48, 4, 337-348, doi : 10.2478/congeo-2018 -0016 .

ESI SAS (Earth Science Institute of the Slovak Academy of Sciences), 2004: National Network of Seismic Stations of Slovakia. Deutsches GeoForschungsZentrum GFZ. Other/Seismic Network, doi: 10.14470/FX099882. 
Fojtíková L., Kristeková M., Málek J., Sokos E., Csicsay K., Záhradník J., 2015: Quantifying capability of a local seismic network in terms of locations and focal mechanism solutions of weak earthquakes. J. Seismol., 20, 1, 93-106, doi : 10.1007/s10950-015 -9512-1.

GEOFON Data Centre, 1993: GEOFON Seismic Network. Deutsches GeoForschungsZentrum GFZ. Other/Seismic Network, doi: 10.14470/TR560404.

Grünthal G. (Ed.), 1998: European Macroseismic Scale 1998. Cahiers du Centre Européen de Géodynamique et de Séismologie, 15, Luxembourg, 101 p., online, accessed 29 October 2020, available from: http://media.gfz-potsdam.de/gfz/sec26/resour ces/documents/PDF/EMS-98_Original_englisch.pdf.

Hetényi G., Plomerová J., Bielik M., Bokelmann G., Csicsay K., Czuba W., Meier T., Šroda P., Wéber Z., Wesztergom V., Žlebčíková H., 2019: Pannonian-CarpathianAlpine Seismic Experiment - an AlpArray Complementary Experiment [Data set]. EIDA, doi : 10.7914/SN/ZJ_2019.

Hók J., Kysel R., Kováč M., Moczo P., Kristek J., Kristeková M., Šujan M., 2016: A seismic source zone model for the seismic hazard assessment of Slovakia. Geol. Carpath., 67, 3, 273-288, doi: 10.1515/geoca-2016-0018.

Institute of Geophysics, Academy of Sciences of the Czech Republic, 1973: Czech Regional Seismic Network. International Federation of Digital Seismograph Networks, Other/Seismic Network, doi: 10.7914/SN/CZ.

Institute of Physics of the Earth Masaryk University (Czech), 2014: IPE_EDU. International Federation of Digital Seismograph Networks, Other/Seismic Network, doi: $10.7914 /$ SN/D1.

Kövesligethy Radó Seismological Observatory (Geodetic and Geophysical Institute, Research Centre for Astronomy and Earth Sciences, Hungarian Academy of Sciences (MTA CSFK GGI KRSZO)), 1992: Hungarian National Seismological Network. Deutsches GeoForschungsZentrum GFZ. Other/Seismic Network, doi : 10.14470/UH 028726.

Liščák P., Petro L., Papčo J., Cipciar A., Csicsay K., Kristeková M., Stercz M., Pacajová K., Bednárik M., Briestenský M., Bella P., 2020: Partial Monitoring System Geological Factors, Subsystem 02: Tectonic and seismic activity of the territory, Geological work number 207, Report for 2019 (Čiastkový monitorovací systém Geologické faktory, Podsystém 02: Tektonická a seizmická aktivita, číslo geologickej úlohy 207, správa za obdobie: rok 2019). State Geological Institute of Dionýz Štúr, Regional centre Košice - in preparation (in Slovak).

Local Seismic Network of Eastern Slovakia. Faculty of Mathematics, Physics of the Earth and Informatics, Comenius University, http://www.fyzikazeme.sk/mainpage/ind ex_en.htm.

Pajdušák P., 1997: Historical seismic instruments at the stations Hurbanovo (HRB) and Skalnaté pleso (SPC) of Slovakia. Cahiers du Centre Européen de Géodynamique et de Séismologie, 13, 49-60.

Polish Seismological Network (PLSN), Institute of Geophysics Polish Academy of Sciences, https://www.igf.edu.pl/stacje-en.php. 
Stammler K., 1993: Seismichandler-Programmable multichannel data handler for interactive and automatic processing of seismological analyses. Comput. Geosci., 19, 2, 135-140, doi : 10.1016/0098-3004 (93) 90110-Q.

Weber B., Becker J., Hanka W., Heinloo A., Hoffmann M., Kraft T., Pahlke D., Reinhardt J., Thoms H., 2007: SeisComp3 - automatic and interactive real time data processing. Geophysical Research Abstracts, EGU General Assembly, 9, 09129.

ZAMG - Zentralanstalt für Meterologie und Geodynamik, 1987: Austrian Seismic Network. International Federation of Digital Seismograph Networks, Other/Seismic Network, doi: 10.7914/SN/OE. 